\title{
Correction: Spontaneous ovarian heterotopic pregnancy
}

Stanley R, Nair A, Fiallo F. Spontaneous ovarian heterotopic pregnancy. BMJ Case Rep 2018. doi: 10.1136/bcr-2018-225619 [Epub ahead of print 9 Aug 2018].

This article contains an error in the authors list. The correct order of authors is: Russell Stanley, Francisco Fiallo, and Anjana Nair.

(C) BMJ Publishing Group Limited 2018. No commercial re-use. See rights and permissions. Published by BMJ.

BMJ Case Rep 2018. doi:10.1136/bcr-2018-225619corr1

(A) Check for updates

Copyright 2018 BMJ Publishing Group. All rights reserved. For permission to reuse any of this content visit http://group.bmj.com/group/rights-licensing/permissions.

BMJ Case Report Fellows may re-use this article for personal use and teaching without any further permission.

Become a Fellow of BMJ Case Reports today and you can:

- Submit as many cases as you like

- Enjoy fast sympathetic peer review and rapid publication of accepted articles

- Access all the published articles

Re-use any of the published material for personal use and teaching without further permission

For information on Institutional Fellowships contact consortiasales@bmjgroup.com

Visit casereports.bmj.com for more articles like this and to become a Fellow 